\title{
PENGARUH UKURAN PERUSAHAAN, INTANGIBLE ASSET VALUE DAN INTELLECTUAL CAPITAL TERHADAP NILAI PERUSAHAAN DENGAN KINERJA KEUANGAN SEBAGAI VARIABEL MODERATING PADA PERUSAHAAN YANG TERDAFTAR DI ISSI PERIODE 2013-2017
}

\author{
Jamilatun Nisa'*, Kiswanto \\ Jurusan Akuntansi, Fakultas Ekonomi, Universitas Negeri Semarang \\ Gedung L2, Lantai 2 FE UNNES, Kampus Sekaran, Gunungpati, Semarang, 50229 \\ E-mail: jamilatunnisa.skripsi@gmail.com
}

\begin{abstract}
ABSTRAK
Penelitian ini bertujuan Mengetahui dan memberikan bukti empiris tentang pengaruh ukuran perusahaan, intangible asset value dan intellectual capital terhadap nilai perusahaan dengan kinerja keuangan sebagai variabel moderating pada perusahaan yang terdaftar di ISSI periode 2013-2017. Populasi dalam penelitian ini adalah perusahaan yang terdaftar di ISSI periode 2013-2017 yang berjumlah 100 perusahaan. Sampel dipilih dengan menggunakan metode purposive sampling, sehingga penentuan sampel yang akan dipilih berdasarkan penilaian kriteria tertentu. Metode analisis data yang digunakan dalam penelitian ini adalah analisis statistik deskriptif dan analisis statistik inferensial yaitu analisis regresi berganda. Hasil penelitian menunjukkan bahwa ukuran perusahaan dan intellectual capital tidak berpengaruh terhadap nilai perusahaan pada perusahaan yang terdaftar di Indeks Saham Syariah Indonesia. Intangible asset value berpengaruh positif signfikan terhadap nilai perusahaan pada perusahaan yang terdaftar di Indeks Saham Syariah Indonesia. Ukuran perusahaan dan intangible asset value tidak berpengaruh terhadap nilai perusahaan dengan dimoderasi oleh kinerja keuangan pada perusahaan yang terdaftar di Indeks Saham Syariah Indonesia. Intellectual Capital berpengaruh positif terhadap nilai perusahaan dengan dimoderasi oleh kinerja keuangan pada perusahaan yang terdaftar di Indeks Saham Syariah Indonesia.
\end{abstract}

Kata Kunci : Ukuran Perusahaan; Intangible Asset Value; Intellectual Capital; Nilai Perusahaan; Kinerja Keuangan.

\begin{abstract}
This study aims to find out and provide empirical evidence about the effect of company size, intangible asset value and intellectual capital on firm value with financial performance as a moderating variable in companies registered at ISSI 2013-2017. The population in this study are companies registered at ISSI 2013-2017, amounting to 100 companies. The sample was selected using the purposive sampling method, so that the determination of the sample to be chosen was based on the evaluation of certain criteria. Data analysis methods used in this study are descriptive statistical analysis and inferential statistical analysis, namely multiple regression analysis. The results showed that company size and intellectual capital had no effect on the value of the company in companies listed on the Indonesian Syariah Stock Index. Intangible asset value has a significant positive effect on the value of the company in companies listed on the Indonesian Syariah Stock Index. The size of the company and the intangible asset value do not affect the value of the company by being moderated by the financial performance of companies listed on the Indonesian Syariah Stock Index. Intellectual Capital has a positive effect on company value by being moderated by the financial performance of companies listed on the Indonesian Syariah Stock Index.
\end{abstract}

Keywords: Company Size; Intangible Asset Value; Intellectual Capital; The value of the company; Financial performance. 


\section{PENDAHULUAN}

Tujuan utama dari suatu perusahaan bukanlah hanya untuk mendapatkan keuntungan yang sebesar besarnya melainkan untuk meningkatkan nilai perusahaan. Nilai perusahaan merupakan sinyal positif berupa informasi yang akan diterima oleh investor, informasi tersebut dapat diterima melalui harga saham perusahaan, keputusan pendanaan, dan kegiatan investasi perusahaan (Sujoko dan Soebiantoro, 2014). Nilai perusahaan yang tinggi menjadi keinginan para pemilik dengan nilai yang tinggi menunjukkan kemakmuran pemegang saham juga tinggi karena perusahaan memiliki prospek yang baik. Nilai perusahaan juga dapat ditunjukkan dari besarnya Price Book Value (PBV) yang merupakan perbandingan antara harga saham dengan nilai buku per lembar saham (Sugiarto, 2011).

Terdapat beberapa alasan mengapa perusahaan perlu memperhatikan nilai perusahaan. Alasan pertama karena tujuan perusahaan didirikan salah satunya ialah untuk memperoleh keuntungan. Perusahaan yang memiliki orientasi untuk memperoleh keuntungan, umumnya akan memfokuskan kegiatannya untuk meningkatkan nilai perusahaan hingga mencapai maksimum. Bagi perusahaan yang menjual sahamnya ke masyarakat (go public), indikator nilai perusahaan adalah harga saham yang diperjualbelikan di Bursa Efek. Pendapat ini didasarkan atas pemikiran bahwa peningkatan harga saham identik dengan peningkatan nilai perusahaan (Rahmawati, dkk, 2015).

Alasan kedua yaitu peranan manajemen dan pemegang saham sangat penting dalam menentukan besarnya keuntungan dan kemakmuran yang kelak diperoleh perusahaan. Salah satu tugas manajer keuangan sebuah perusahaan adalah memperhatikan kemakmuran para pemegang saham atau investor. Hal tersebut disebabkan investor akan menitikberatkan pada harga pasar saham atau nilai pasar untuk mengetahui perkembangan nilai perusahaan (Rahmawati, dkk, 2015). Penurunan nilai harga saham sebagai indikator nilai perusahaan, pada beberapa perusahaan yang terdaftar di Bursa Efek Indonesia selama periode 2014-2015 sebagaimana dalam tabel 1 berikut :

Tabel 1 Penurunan Harga Saham Perusahaan Periode 2014-2016

\begin{tabular}{|l|l|c|c|c|}
\hline \multirow{2}{*}{ No. } & \multicolumn{1}{|c|}{ Nama Perusahaan } & \multicolumn{3}{|c|}{ Harga Saham (Rp) } \\
\cline { 3 - 5 } & & 2014 & 2015 & 2016 \\
\hline 1. & Indocement Tunggal Prakarsa Tbk. & 25000 & 22325 & 15400 \\
\hline 2. & Indofood CBP Sukses Makmur Tbk. & 13100 & 13485 & 8575 \\
\hline 3. & Astra International Tbk. & 7425 & 6000 & 8275 \\
\hline 4. & Indofood Sukses Makmur Tbk. & 6750 & 5175 & 7925 \\
\hline
\end{tabular}




\begin{tabular}{|l|l|l|l|l|}
\hline 5. & Charoen Pokphand Indonesia Tbk. & 3780 & 2600 & 3090 \\
\hline 6. & Adhi Karya Tbk. & 3480 & 2140 & 2080 \\
\hline 7. & Tiga Pilar Sejahtera Food Tbk. & 2095 & 1210 & 1945 \\
\hline 8. & Akasha Wira International Tbk. & 1375 & 1015 & 1000 \\
\hline
\end{tabular}

Sumber : www.idx.co.id, 2019.

Berdasarkan tabel 1.1 dapat diketahui bahwa beberapa saham yang terdaftar di Bursa Efek Indonesia selama periode 2014-2015 mengalami penurunan nilai harga per lembar saham. Astra Agro Lestari, Tbk mengalami penurunan Rp. 8.400 dari tahun sebelumnya. Nilai perusahaan juga dapat dilihat dari rasio PBV, kenyataan menunjukkan bahwa perusahaan yang masih memiliki nilai PBV yang kurang dari 1 (satu) berarti perusahaan memiliki nilai yang rendah karena para investor membeli saham lebih murah daripada nilai bukunya, sebagaimana dalam tabel 2 berikut :

Tabel 2 Penurunan Price Book Value Perusahaan Periode 2014-2015

\begin{tabular}{|c|c|c|c|c|}
\hline \multirow{2}{*}{ No. } & \multirow{2}{*}{ Nama Perusahaan } & \multicolumn{2}{|c|}{ Price Book Value } & \multirow{2}{*}{$\begin{array}{l}\text { Penurunan } \\
\text { (poin) }\end{array}$} \\
\hline & & 2014 & 2015 & \\
\hline 1. & Indocement Tunggal Prakarsa Tbk. & 3,71 & 3,71 & 0,0 \\
\hline 2. & Indofood CBP Sukses Makmur Tbk. & 5,08 & 5,08 & 0,0 \\
\hline 3. & Astra International Tbk. & 2,5 & 2,5 & 0,0 \\
\hline 4. & Indofood Sukses Makmur Tbk. & 1,44 & 1,44 & 0,0 \\
\hline 5. & Charoen Pokphand Indonesia Tbk. & 5,66 & 5,66 & 0,0 \\
\hline 6. & Adhi Karya Tbk. & 3,58 & 1,48 & 2,1 \\
\hline 7. & Tiga Pilar Sejahtera Food Tbk. & 1,88 & 0,98 & 0,9 \\
\hline 8. & Akasha Wira International Tbk. & 2,74 & 2,74 & 0,0 \\
\hline
\end{tabular}

Sumber : www.idx.co.id, 2019.

Berdasarkan tabel 1.2 dapat diketahui bahwa beberapa saham perusahaan selama periode 2014-2015 mengalami penurunan nilai price book value. Penurunan nilai PBV tersebut menunjukkan bahwa investor membeli saham lebih murah daripada nilai bukunya. Penurunan nilai perusahaan yang dilihat dari harga pasar saham akan mengakibatkan pada pandangan negatif investor terhadap kinerja perusahaan sehingga perusahaan harus berusaha meningkatkan nilai perusahaannya agar menarik perhatian investor untuk menanamkan dananya pada perusahaan tersebut.

Dari hasil penelitian terdahulu diperoleh beberapa perbedaan hasil penelitian antara lain dalam penelitian Isnaini (2016) serta hasil penelitian Kurniawan dan Mertha (2016) menunjukkan bahwa nilai aset tidak berwujud berpengaruh positif dan signifikan terhadap 
nilai perusahaan. Namun dalam penelitian Setijawan (2015) dan Kombih dan Suhardianto (2017) menunjukkan bahwa nilai aset tidak berwujud sebuah perusahaan yang diindikatorkan dengan goodwill tidak terbukti berpengaruh terhadap nilai perusahaan.

Adanya pengaruh signifikan positif intellectual capital terhadap nilai perusahaan didukung oleh penelitian Sukiati, dkk (2015) yang menunjukkan bahwa intellectual capital yang diproksikan dengan human capital, customer capital, innovation capital, dan process capital berpengaruh positif terhadap nilai perusahaan. Sedangkan penelitian Setiono dan Hartono (2016) menunjukkan bahwa intellectual capital yang diindikatorkan dengan intensitas tenaga kerja tidak berpengaruh positif terhadap nilai perusahaan.

Tujuan dari penelitian ini adalah mengetahui dan memberikan bukti empiris tentang pengaruh ukuran perusahaan, intangible asset value dan intellectual capital terhadap nilai perusahaan pada perusahaan yang terdaftar di Indeks Saham Syariah Indonesia periode 20132017. Mengetahui dan memberikan bukti empiris tentang pengaruh ukuran perusahaan, intangible asset value dan intellectual capital terhadap nilai perusahaan dengan dimoderasi oleh kinerja keuangan pada perusahaan yang terdaftar di Indeks Saham Syariah Indonesia periode 2013-2017.

Penelitian ini dilandasi oleh dua teori yaitu teori signal dan resource based theory. Pertama, signaling theory ini juga menyatakan bahwa perusahaan akan selalu berusaha untuk mengirim sinyal berupa informasi positif atau kabar baik kepada investor dan pemegang saham dengan menggunakan mekanisme pengungkapan, salah satunya melalui media laporan tahunan. Menurut Jogiyanto (2003), informasi yang dipublikasikan sebagai suatu pengumuman akan memberikan signal bagi investor dalam pengambilan keputusan investasi.

Kedua, Resources Based Theory membahas mengenai sumber daya yang dimiliki perusahaan dan bagaimana perusahaan tersebut dapat mengelola dan memanfaatkan sumber daya yang dimilikinya. Wernerfelt, menjelaskan bahwa menurut pandangan RBV, perusahaan akan unggul dalam persaingan usaha dan mendapatkan kinerja keuangan yang baik dengan cara memiliki, menguasai dan memanfaatkan aset-aset strategis yang penting (aset berwujud dan tidak berwujud). Belkaoui dalam Fransiskus dan Solon menyatakan strategi yang potensial untuk meningkatkan kinerja perusahaan adalah dengan menyatukan aset berwujud dan aset tidak berwujud (Randa dan Solon, 2012). 
Berdasar pada teori sinyal yang dikemukakan oleh Spence (1973), yang menyatakan bahwa ukuran sebuah perusahaan yang tercermin dalam laporan keuangan merupakan sinyal positif bagi investor mengenai prospek masa depan perusahaan. Ukuran perusahaan menggambarkan besar kecilnya aktiva yang dimiliki suatu perusahaan. Semakin tinggi tingkat profitabilitas, akan membuat harga pasar saham suatu perusahaan meningkat, sehingga nilai perusahaan juga turut meningkat (Rahmawati, 2015).

Nilai perusahaan diartikan sebagai harga yang bersedia dibayar investor apabila perusahaan akan dijual. Nilai perusahaan merupakan harga jual perusahaan yang dianggap layak oleh calon investor sehingga investor tersebut mau membayarnya, jika suatu perusahaan akan dilikuidasi (Rahmawati, 2015).

Perusahaan dengan ukuran lebih besar akan menjadi lebih efisien karena kemungkinan untuk mengeksploitasi skala ekonomi, memperkerjakan manajer yang lebih terampil dan memiliki formalisasi prosedur yang baik, membuat perusahaan memiliki kinerja yang lebih baik. Semakin besar ukuran perusahaan, perusahaan lebih mudah dalam memperoleh modal eksternal dan membuat investor tertarik untuk menanamkan sahamnya (Kinanti dan Nuzula, 2017).

Adanya pengaruh signifikan positif ukuran perusahaan terhadap nilai perusahaan didukung oleh penelitian Kinanti dan Nuzula (2017). Hasil penelitian ini menunjukkan bahwa ukuran perusahaan yang diproksikan dengan logaritma natural total aset berpengaruh positif terhadap nilai perusahaan. Penelitian lain yang memiliki hasil serupa adalah penelitian yang dilakukan oleh Rahmawati, dkk (2015) yang menyatakan bahwa ukuran perusahaan berpengaruh positif terhadap nilai perusahaan.

H1: Ukuran perusahaan berpengaruh positif terhadap nilai perusahaan pada perusahaan yang terdaftar di Indeks Saham Syariah Indonesia periode 2013-2017.

Berdasarkan Resource Based Theory (RBT), perusahaan harus memiliki sumber daya yang lebih superior dibandingkan perusahaan lain untuk dapat menciptakan keunggulan kompetitif. Menurut Lev dan Daum sebagaimana dikutip Soraya, mengemukakan bahwa aset tidak berwujud memiliki peran penting dalam mencapai tujuan dan strategi perusahaan serta dalam menentukan nilai perusahaan. Salah satu wujud dari peran penting tersebut dapat dilihat dari penggunaan pengetahuan yang menghasilkan inovasi serta sebagai landasan untuk meningkatkan responsivitas terhadap kebutuhan pelanggan dan stakeholders. Manfaat yang diperoleh perusahaan dari meningkatnya kompetensi karyawan dan adanya inovasi adalah 
meningkatnya competitive advantage. Akibatnya, semakin tinggi nilai aset tidak berwujud, maka semakin tinggi pula nilai perusahaan.

Nilai perusahaan merupakan nilai pasar atas surat berharga hutang dan ekuitas perusahaan yang beredar. Harga saham yang tinggi membuat nilai perusahaan juga tinggi. Nilai perusahaan yang tinggi akan membuat pasar percaya tidak hanya pada kinerja perusahaan saat ini namun juga pada prospek perusahaan di masa depan (Abadiah, dkk, 2016).

Terdapat pengaruh positif yang signifikan antara aset tidak berwujud terhadap nilai perusahaan. Hal ini menunjukkan bahwa semakin tinggi nilai dari total asset yang mana komponen penyusunnya adalah asset tidak berwujud maka akan semakin besar nilai perusahaan dan semakin baik pula presepsi investor terhadap sebuah perusahan. Adanya pengaruh signifikan positif nilai aset tidak berwujud terhadap nilai perusahaan didukung oleh penelitian Abadiah, Hidayati dan Mawardi (2016) serta Isnaini (2016). Hasil penelitian ini menunjukkan bahwa nilai aset tidak berwujud yang diproksikan dengan selisih lebih nilai perusahaan (CMV) dari nilai buku aset bersih (BVNA) berpengaruh positif terhadap nilai perusahaan. Penelitian lain yang memiliki hasil serupa adalah penelitian yang dilakukan oleh Kurniawan dan Mertha (2016) yang menyatakan bahwa nilai aset tidak berwujud berpengaruh positif terhadap nilai perusahaan.

\section{H2: Intangible Asset Value berpengaruh positif terhadap nilai perusahaan pada perusahaan yang terdaftar di Indeks Saham Syariah Indonesia periode 2013-2017.}

Berdasarkan Resource Based Theory (RBT), perusahaan harus memiliki sumber daya yang lebih superior dibandingkan perusahaan lain untuk dapat menciptakan keunggulan kompetitif. Penelitian ini menggunakan kerangka intellectual capital dimana komponen intellectual capital diidentifikasikan dalam konsep input-proses-output untuk menggambarkan hubungan antara sumber daya dan nilai dalam proses penciptaan nilai. Keempat komponen intellectual capital: innovation capital, process capital, human capital, dan customer capital berasal dari persepsi manajerial dan tidak secara langsung diukur dalam laporan keuangan. Komponen-komponen intellectual capital tersebut menjadi innovative capacity, efficient operating processes, human value added, dan maintainable customer relationship sehingga ukuran keuangan dapat digunakan untuk mengembangkan model jalur struktural yang menghubungkan antara intellectual capital dan kinerja perusahaan. 
Perhatian terhadap modal intelektual semakin hari semakin meningkat. Akademisi dan praktisi mulai tertarik untuk meneliti perkembangan modal intelektual karena perusahaan yang menginvestasikan modal intelektualnya lebih besar menghasilkan hidden value yang semakin tinggi. Selisih nilai pasar dengan nilai buku merupakan hidden value perusahaan. Hidden value yang dimaksud di pengaruhi oleh modal intelektual.

Adanya pengaruh signifikan positif intellectual capital terhadap nilai perusahaan didukung oleh penelitian Rachman dan Marsono (2014). Hasil penelitian ini menunjukkan bahwa intellectual capital yang diproksikan dengan human capital, customer capital, innovation capital, dan process capital berpengaruh positif terhadap nilai perusahaan. Penelitian lain yang memiliki hasil serupa adalah penelitian yang dilakukan oleh Yusuf dan Gasim (2015) serta Sukiati, dkk (2015) yang menyatakan bahwa intellectual capital berpengaruh positif terhadap nilai perusahaan.

\section{H3: Intellectual capital berpengaruh positif terhadap nilai perusahaan pada perusahaan yang terdaftar di Indeks Saham Syariah Indonesia periode 2013-2017.}

Jansen dan Meckling (1976) menggambarkan hubungan keagenan sebagai hubungan yang timbul karena adanya kontrak antara principal (pemegang saham) yang menggunakan agent (manajemen pengelola perusahaan) untuk melakukan jasa. Salah satu faktor yang dapat dijadikan sebagai dasar pertimbangan dalam pengambilan keputusan investasi adalah kinerja keuangan perusahaan. Semakin baik kinerja keuangan perusahaan, maka akan menarik semakin banyak investor yang pada akhirnya dapat menaikkan nilai perusahaan karena banyaknya permintaan terhadap saham perusahaan (Rachman dan Marsono, 2014).

Perusahaan besar lebih konsisten untuk tepat waktu dibanding perusahaan kecil dalam mengnformasikan laporan keuangannya, karena perusahaan besar banyak disorot oleh masyarakat. Perusahaan besar mempunyai pengetahuan lebih tentang peraturan yang ada, oleh karena itu perusahaan besar lebih mentaati peraturan mengenai ketepatan waktu dibanding perusahaan kecil. Namun demikian tidak menutup kemungkinan bahwa perusahaan besar cenderung melaporkan laporan keuangannya tidak tepat waktu mengingat banyaknya cabang usaha serta banyaknya anak perusahaan yang dimilikinya, sehingga penyusunan laporan keuangan akan lebih rumit dan lama.

Adanya pengaruh signifikan positif ukuran perusahaan terhadap nilai perusahaan didukung oleh penelitian Kinanti dan Nuzula (2017). Hasil penelitian ini menunjukkan bahwa ukuran perusahaan yang diproksikan dengan logaritma natural total aset berpengaruh positif 
terhadap nilai perusahaan. Penelitian lain yang memiliki hasil serupa adalah penelitian yang dilakukan oleh Rahmawati, dkk (2017) yang menyatakan bahwa ukuran perusahaan berpengaruh positif terhadap nilai perusahaan.

\section{H4: Ukuran perusahaan berpengaruh positif terhadap nilai perusahaan dengan dimoderasi oleh kinerja keuangan pada perusahaan yang terdaftar di Indeks Saham Syariah Indonesia periode 2013-2017.}

Berdasarkan Resource Based Theory (RBT), perusahaan harus memiliki sumber daya yang lebih superior dibandingkan perusahaan lain untuk dapat menciptakan keunggulan kompetitif. Aset tidak berwujud memiliki peran penting dalam mencapai tujuan dan strategi perusahaan serta dalam menentukan nilai perusahaan. Salah satu wujud dari peran penting tersebut dapat dilihat dari penggunaan pengetahuan yang menghasilkan inovasi serta sebagai landasan untuk meningkatkan responsivitas terhadap kebutuhan pelanggan dan stakeholders (Soraya dan Syafruddin, 2016).

Meskipun aset tidak berwujud telah disajikan dalam laporan keuangan, namun masih ada unexplained value yang tidak disajikan dalam laporan keuangan. Unexplained value tersebut biasanya berasal dari aset tidak berwujud yang dihasilkan secara internal oleh perusahaan. Salah satu penyebab adanya unexplained value adalah ketidakkonsistenan standar akuntansi terkait pengukuran dan pelaporan aset tidak berwujud dalam laporan keuangan. Salah satu contohnya adalah ketidakjelasan perlakuan aset tidak berwujud baik yang dihasilkan secara internal maupun dari kombinasi bisnis (merger atau akuisisi) apakah akan dikapitalisasi atau dibebankan. The Financial Accounting Standards Board (FASB) pun belum mengambil langkah-langkah yang memungkinkan aset tidak berwujud yang dihasilkan secara internal dikapitalisasi. Dengan beberapa pengecualian, standar akuntansi mensyaratkan bahwa aset tidak berwujud yang dihasilkan secara internal diperlakukan sebagai beban (Soraya dan Syafruddin, 2016).

Adanya pengaruh signifikan positif ukuran perusahaan terhadap nilai perusahaan didukung oleh penelitian Kinanti dan Nuzula (2017). Hasil penelitian ini menunjukkan bahwa ukuran perusahaan yang diproksikan dengan logaritma natural total aset berpengaruh positif terhadap nilai perusahaan. Penelitian lain yang memiliki hasil serupa adalah penelitian yang dilakukan oleh Rahmawati, dkk (2017) yang menyatakan bahwa ukuran perusahaan berpengaruh positif terhadap nilai perusahaan. 


\section{H5: Intangible Asset Value berpengaruh positif terhadap nilai perusahaan dengan dimoderasi oleh kinerja keuangan pada perusahaan yang terdaftar di Indeks Saham Syariah Indonesia periode 2013-2017.}

Berdasarkan Resource Based Theory (RBT), perusahaan harus memiliki sumber daya yang lebih superior dibandingkan perusahaan lain untuk dapat menciptakan keunggulan kompetitif. Dasar pemikiran utama RBT menyatakan bahwa kemampuan menciptakan nilai perusahaan tidak berasal dari dinamika industri perusahaan, tetapi berasal dari proses organisasional yang mengarahkan pada keistimewaan sumber daya yang dimiliki. RBT mengkaji sifat dasar dan kualitas sumber daya dalam proses penciptaan nilai, tetapi tidak menyediakan suatu kerangka yang menjelaskan proses persebaran dan bagaimana nilai perusahaan terbentuk; hubungan antara sumber daya (input) dan nilai perusahaan (output) terasumsikan dalam kerangka, tetapi tidak dijelaskan (Rachman dan Marsono, 2014).

Oleh karena itu, RBT tidak mampu menggambarkan proses penciptaan nilai yang terjadi, sehingga manajer tidak dapat mengetahui kerangka kerja yang tepat untuk menjelaskan bagaimana input sumber daya menjadi output selama proses penciptaan nilai. Perspektif intellectual capital kemudian muncul menyediakan jembatan penghubung antara sumber daya dan nilai dengan memfokuskannya pada pencarian metode terbaik untuk mengolah dan memanfaatkan nilai maksimum dari sumber daya yang ada. Penelitian ini menggunakan kerangka intellectual capital dimana komponen intellectual capital diidentifikasikan dalam konsep input-proses-output.

Keempat komponen intellectual capital: innovation capital, process capital, human capital, dan customer capital berasal dari persepsi manajerial dan tidak secara langsung diukur dalam laporan keuangan. Komponen-komponen intellectual capital tersebut menjadi innovative capacity, efficient operating processes, human value added, dan maintainable customer relationship sehingga ukuran keuangan dapat digunakan untuk mengembangkan model jalur struktural yang menghubungkan antara intellectual capital dan kinerja perusahaan.

Adanya pengaruh signifikan positif kinerja keuangan terhadap nilai perusahaan didukung oleh penelitian Abadiah, Hidayati dan Mawardi (2016) serta Kombih dan Suhardianto (2017). Hasil penelitian ini menunjukkan bahwa kinerja keuangan yang diproksikan dengan return on asset (ROA) berpengaruh positif terhadap nilai perusahaan. Hasil penelitian Yusuf dan Gasim (2015) menunjukkan bahwa intellectual capital yang 
diproksikan dengan human capital, customer capital, innovation capital, dan process capital berpengaruh positif terhadap nilai perusahaan.

\section{H6: Intellectual capital berpengaruh positif terhadap nilai perusahaan dengan} dimoderasi oleh kinerja keuangan pada perusahaan yang terdaftar di Indeks Saham Syariah Indonesia periode 2013-2017.

Berdasarkan kerangka berpikir diatas, dapat digambarkan seperti Gambar 1 berikut ini:

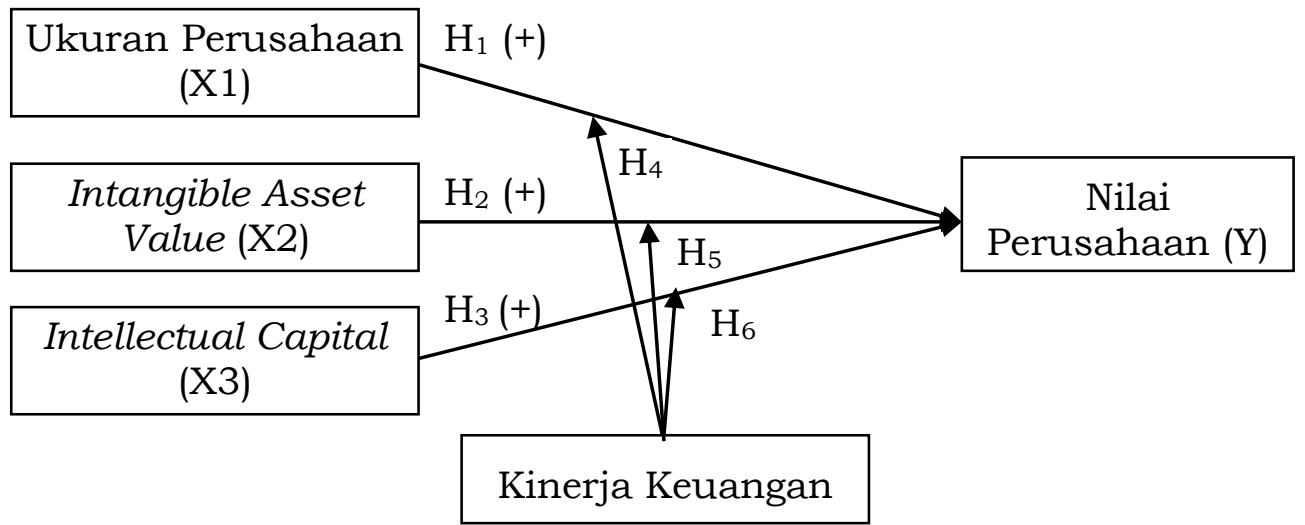

Gambar 1. Kerangka Berpikir

Sumber : Abadiah, dkk (2016) yang dikembangkan guna penelitian ini.

\section{METODE PENELITIAN}

Penelitian ini adalah penelitian kuantitatif yang memanfaatkan data sekunder dari laporan tahunan (annual report) yang sudah dipublikasikan secara resmi oleh Indonesia Stock Exchange pada laman webnya www.idx.co.id serta laman web resmi perusahaan keuangan pada tahun 2013-2016. Penelitian ini menggunakan metode purposive sampling, sampel dalam penelitian adalah perusahaan yang terdaftar di ISSI periode 2013-2017 yang berjumlah 100 perusahaan.

Penelitian ini menggunakan variabel ukuran perusahaan, intangible asset value dan intellectual capital sebagai variabel independen. Variabel dependen dalam penelitian ini adalah nilai perusahaan. Variabel moderasi dalam penelitian ini adalah kinerja keuangan. Definisi operasional antar variabel dapat dilihat pada Tabel 3 sebagai berikut: 
Tabel 3 Definisi Operasional Variabel

\begin{tabular}{|c|c|c|c|}
\hline No & Variabel & Definisi Operasional Variabel & Indikator \\
\hline 1 & $\begin{array}{l}\text { Ukuran } \\
\text { Perusahaan } \\
\text { (X1) }\end{array}$ & $\begin{array}{l}\text { Ukuran perusahaan adalah } \\
\text { rasio yang menunjukan skala } \\
\text { untuk menentukan besar } \\
\text { kecilnya ukuran perusahaan. } \\
\text { Ukuran perusahaan dalam } \\
\text { penelitian ini dinilai dengan } \\
\text { log of total assets (Nuraeni, } \\
\text { dkk, 2015). }\end{array}$ & $\begin{array}{l}\text { Size = logaritma natural total Asset } \\
\text { Arif Pajar dan Deny Dwi (2016). }\end{array}$ \\
\hline 2 & $\begin{array}{l}\text { Intangible } \\
\text { Asset Value } \\
\text { (X2) }\end{array}$ & $\begin{array}{l}\text { Intangible Asset Value adalah } \\
\text { mencerminkan hak/hak } \\
\text { istimewa atau posisi yang } \\
\text { menguntungkan perusahaan } \\
\text { dalam menghasilkan } \\
\text { pendapatan (Halim, 2007). }\end{array}$ & $\begin{array}{c}\text { CMV = Jumlah Saham Beredar x } \\
\text { Harga Saham Penutupan } \\
\text { Akhir Tahun } \\
\text { BVNA = Total Aset }- \text { Total } \\
\text { Kewajiban } \\
\text { INTAV = CMV - BVNA } \\
\text { Kurniawan dan Mertha (2016) }\end{array}$ \\
\hline 3 & $\begin{array}{l}\text { Intellectual } \\
\text { Capital (X3) }\end{array}$ & $\begin{array}{lr}\text { Intellectual capital } \\
\text { merupakan } & \text { sebuah } \\
\text { sumberdaya penting dan } \\
\text { sebuah kapabilitas untuk } \\
\text { bertindak berdasarkan } \\
\text { pengetahuan (Kurniawan dan } \\
\text { Mertha, 2016). }\end{array}$ & $\begin{array}{r}\text { CEE }=\frac{\text { Value added }}{\text { Capital employed }} \\
\mathrm{HCE}=\frac{\text { Value added }}{\text { Human capital }} \\
\mathrm{SCE}=\frac{\text { VA }- \text { human capital }}{\text { Value added }} \\
\text { VAIC }=\mathrm{SCE}+\mathrm{HCE}+\mathrm{CEE} \\
\text { Kurniawan dan Mertha }(2016)\end{array}$ \\
\hline 4 & $\begin{array}{l}\text { Kinerja } \\
\text { Keuangan (Z) }\end{array}$ & $\begin{array}{l}\text { Rasio ini mengukur } \\
\text { kemampuan perusahaan } \\
\text { dalam menghasilkan laba dari } \\
\text { total aktiva yang digunakan. } \\
\text { Rasio ini diukur dengan cara } \\
\text { laba bersih sebelum pajak } \\
\text { dibagi dengan total aset yang } \\
\text { dilaporkan dalam neraca } \\
\text { (Kurniawan dan Mertha, } \\
\text { 2016). }\end{array}$ & $\begin{array}{c}\text { ROA }=\frac{\text { Net Profit Before Tax }}{\text { Total Aset }} \\
\text { Kurniawan dan Mertha (2016) }\end{array}$ \\
\hline 5 & $\begin{array}{l}\text { Nilai } \\
\text { Perusahaan } \\
\text { (Y) }\end{array}$ & $\begin{array}{l}\text { Nilai perusahaan adalah nilai } \\
\text { sekarang dari arus pendapatan } \\
\text { atau kas yang diharapkan } \\
\text { diterima pada masa yang } \\
\text { akan datang (Nuraeni, dkk, } \\
\text { 2015). }\end{array}$ & PBV $=\frac{\text { Nilai Saham }}{\text { Nilai Buku Saham }}$ \\
\hline
\end{tabular}

Sumber: Berbagai Sumber yang Diolah, 2020

Metode pengumpulan data pada penelitian ini adalah dokumentasi. Data yang digunakan berupa laporan keuangan tahunan perusahaan yang terdaftar di Indeks Saham Syariah Indonesia yang diunduh melalui website resmi Bursa Efek Indonesia yaitu 
www.idx.co.id. Pengujian hipotesis dilakukan dengan analisis regresi berganda dengan terlebih dahulu melakukan uji asumsi klasik.

\section{HASIL DAN PEMBAHASAN}

Hasil dari statistik deskriptif variabel ukuran perusahaan, intangible asset value, intellectual capital, kinerja keuangan dan nilai perusahaan disajikan pada Tabel 4.

Tabel 4 Statistik Deskriptif

\begin{tabular}{lrrrrr}
\hline & $\mathrm{N}$ & \multicolumn{1}{c}{ Minimum } & Maximum & \multicolumn{1}{c}{ Mean } & \multicolumn{1}{c}{ Std. Deviation } \\
\hline ukuran perusahaan & 100 & 23.56 & 33.37 & 29.5039 & 2.12240 \\
intangible asset & 100 & 22.50 & 35.62 & 28.9823 & 2.60538 \\
value & & -1.63 & 6.60 & 2.7164 & 1.56976 \\
intellectual capital & 100 & .00 & 1.39 & .1034 & .15310 \\
kinerja keuangan & 100 & -.98 & 8.74 & 2.6738 & 2.03332 \\
nilai perusahaan & 100 & & & & \\
Valid N (listwise) & 100 & & & & \\
\hline
\end{tabular}

Sumber: Data Diolah, 2020

Nilai rata-rata (mean) dari variabel ukuran perusahaan, intangible asset value, intellectual capital dan nilai perusahaan lebih besar dari nilai standar deviasi, sehingga data pada penelitian ini merupakan data yang homogen, sedangkan variabel kinerja keuangan memiliki nilai rata-rata yang lebih kecil dari nilai standar deviasi, sehingga data pada variabel tersebut merupakan data yang heterogen.

Uji asusmsi klasik dilakukan untuk menjadikan model regresi dapat digunakan untuk keperluan estimasi serta mengurangi bias data. Uji asumsi klasik yang dilakukan meliputi uji normalitas, uji multikolinearitas, uji autokorelasi dan uji heterokedastisitas. Hasil uji normalitas menunjukkan diperoleh nilai sig ( $\rho$ value) dari test statistic adalah sebesar 0,081 yang lebih besar dari 0,05, sehingga dapat disimpulkan bahwa nilai residual regresi adalah normal. Dengan demikian asumsi normalitas terpenuhi. Uji multikolinearitas menunjukkan bahwa tidak terjadi gejala multikolinieritas pada semua variabel penjelas yang digunakan yaitu ukuran perusahaan, intangible asset value, intellectual capital dan kinerja keuangan karena semua nilai vif kurang dari angka 10. Hasil uji autokorelasi menunjukkan bahwa nilai DW 2,023 diantara $\mathrm{du}<\mathrm{DW}<4$-du yaitu $(1,7582<2,023<2,2418)$ maka sesuai kaidah pengambilan keputusan disimpulkan bahwa tidak terdapat autokorelasi positif maupun negatif pada model regresi. Hasil uji heterokedastisitas menunjukkan bahwa tidak terdapat heteroskedastisitas antara variabel independen dengan variabel dependen artinya variance residual satu pengamatan ke pengamatan yang lain berbeda, yaitu jika nilai signifikansi 
menunjukkan nilai yang lebih besar dari 0,05 , sehingga model regresi layak dipakai untuk menganalisis pengaruh ukuran perusahaan, intangible asset value dan intellectual capital terhadap nilai perusahaan dengan kinerja keuangan sebagai variabel moderating pada perusahaan yang terdaftar di Indeks Saham Syariah Indonesia Periode 2013-2017.

Hasil menunjukkan bahwa data sudah lolos dari uji asumsi klasik, yang kemudian dilanjutkan dengan uji hipotesis. Nilai koefisien determinasi dari adjusted $R^{2}$ yaitu sebesar 0,436 atau 43,6\%, yang artinya 43,6\% dari variabel nilai perusahaan dapat dijelaskan oleh variabel independen dalam penelitian ini yaitu ukuran perusahaan, intangible asset value, intellectual capital dan kinerja keuangan. Untuk sisanya yaitu 56,4\% dipengaruhi oleh variabel lain yang tidak termasuk dalam model penelitian ini. Tingkat signifikansi dalam penelitian ini adalah 5\% atau 0,05 ( $\square$ ). Hasil dari pengujian hipotesis dapat dilihat di Tabel 5. Persamaan regresi dalam penelitian ini adalah:

$Y=-2,252-0,355 X_{1}+0,501 X_{2}+0,118 X_{3}+56,101 Z-4,583 X_{1} Z+3,178 X_{2} Z-3,201 X_{3} Z-$ $+\mathrm{e}$

Tabel 5. Ringkasan Pengujian Hipotesis

\begin{tabular}{llcccc}
\hline No & \multicolumn{1}{c}{ Variabel } & Koefisien & Sig & Hasil \\
1. $\begin{array}{l}\text { Ukuran perusahaan berpengaruh positif } \\
\text { terhadap nilai perusahaan }\end{array}$ & $-1,629$ & 0,107 & ditolak \\
2. $\begin{array}{l}\text { Intangible Asset Value berpengaruh positif } \\
\text { terhadap nilai perusahaan }\end{array}$ & 3,182 & 0,002 & diterima \\
3. $\quad \begin{array}{l}\text { Intellectual capital berpengaruh positif } \\
\text { terhadap nilai perusahaan }\end{array}$ & 0,917 & 0,361 & ditolak \\
4. Ukuran perusahaan berpengaruh positif \\
$\begin{array}{l}\text { terhadap nilai perusahaan dengan dimoderasi } \\
\text { oleh kinerja keuangan }\end{array}$
\end{tabular}

Sumber : Data Diolah, 2020

\section{Pengaruh Ukuran Perusahaan terhadap Nilai Perusahaan}

Ukuran perusahaan tidak berpengaruh terhadap nilai perusahaan pada perusahaan yang terdaftar di Indeks Saham Syariah Indonesia. Berdasarkan perhitungan t hitung bernilai negatif sedangkan hipotesis penelitian bernilai positif. Tidak sesuai dengan teori sinyal yang dikemukakan oleh Spence (1973), yang menyatakan bahwa ukuran sebuah perusahaan yang 
tercermin dalam laporan keuangan merupakan sinyal positif bagi investor mengenai prospek masa depan perusahaan.

Ukuran perusahaan menggambarkan besar kecilnya aktiva yang dimiliki suatu perusahaan. Ukuran perusahaan dapat dikatakan sebagai kemampuan perusahaan dalam menyediakan jumlah dan berbagai kapasitas produksi atau jasa. Semakin tinggi tingkat profitabilitas, akan membuat harga pasar saham suatu perusahaan meningkat, sehingga nilai perusahaan juga turut meningkat (Rahmawati, 2015).

Nilai perusahaan diartikan sebagai harga yang bersedia dibayar investor apabila perusahaan akan dijual. Berkaitan dengan hal tersebut, nilai perusahaan merupakan harga jual perusahaan yang dianggap layak oleh calon investor sehingga investor tersebut mau membayarnya, jika suatu perusahaan akan dilikuidasi (Rahmawati, 2015).

Tidak adanya pengaruh signifikan positif ukuran perusahaan terhadap nilai perusahaan tidak sesuai dengan hasil penelitian Kinanti dan Nuzula (2017). Hasil penelitian ini menunjukkan bahwa ukuran perusahaan yang diproksikan dengan logaritma natural total aset berpengaruh positif terhadap nilai perusahaan. Penelitian lain juga memiliki hasil yang tidak serupa adalah penelitian yang dilakukan oleh Rahmawati, dkk (2015) yang menyatakan bahwa ukuran perusahaan berpengaruh positif terhadap nilai perusahaan.

\section{Pengaruh Intangible Asset Value terhadap Nilai Perusahaan}

Intangible asset value berpengaruh positif signfikan terhadap nilai perusahaan pada perusahaan yang terdaftar di Indeks Saham Syariah Indonesia. Semakin besar dan baik nilai aset tidak berwujud yang dimiliki perusahaan akan semakin meningkatkan nilai perusahaan di hadapan investor.

Berdasarkan Resource Based Theory (RBT), perusahaan harus memiliki sumber daya yang lebih superior dibandingkan perusahaan lain untuk dapat menciptakan keunggulan kompetitif. Menurut Lev dan Daum sebagaimana dikutip Soraya, mengemukakan bahwa aset tidak berwujud memiliki peran penting dalam mencapai tujuan dan strategi perusahaan serta dalam menentukan nilai perusahaan. Salah satu wujud dari peran penting tersebut dapat dilihat dari penggunaan pengetahuan yang menghasilkan inovasi serta sebagai landasan untuk meningkatkan responsivitas terhadap kebutuhan pelanggan dan stakeholders. Pengetahuan juga bermanfaat untuk meningkatkan produktivitas dan kompetensi karyawan yang telah diberi tanggung jawab. Manfaat yang diperoleh perusahaan dari meningkatnya kompetensi karyawan dan adanya inovasi adalah meningkatnya competitive advantage. Akibatnya, 
semakin tinggi nilai aset tidak berwujud, maka semakin tinggi pula nilai perusahaan. Oleh karena itu, aset tidak berwujud perlu dilaporkan dalam neraca untuk menyediakan informasi akuntansi yang relevan mengenai nilai perusahaan yang sesungguhnya.

Terdapat pengaruh positif yang signifikan antara aset tidak berwujud terhadap nilai perusahaan. Hal ini menunjukkan bahwa semakin tinggi nilai dari total asset yang mana komponen penyusunnya adalah asset tidak berwujud maka akan semakin besar nilai perusahaan dan semakin baik pula presepsi investor terhadap sebuah perusahan. Adanya pengaruh signifikan positif nilai aset tidak berwujud terhadap nilai perusahaan didukung oleh penelitian Abadiah, Hidayati dan Mawardi (2016) serta Isnaini (2016). Hasil penelitian ini menunjukkan bahwa nilai aset tidak berwujud yang diproksikan dengan selisih lebih nilai perusahaan (CMV) dari nilai buku aset bersih (BVNA) berpengaruh positif terhadap nilai perusahaan. Penelitian lain yang memiliki hasil serupa adalah penelitian yang dilakukan oleh Kurniawan dan Mertha (2016) yang menyatakan bahwa nilai aset tidak berwujud berpengaruh positif terhadap nilai perusahaan.

\section{Pengaruh Intellectual Capital terhadap Nilai Perusahaan}

Intellectual capital tidak berpengaruh terhadap nilai perusahaan pada perusahaan yang terdaftar di Indeks Saham Syariah Indonesia. Tidak sesuai dengan Resource Based Theory (RBT), perusahaan harus memiliki sumber daya yang lebih superior dibandingkan perusahaan lain untuk dapat menciptakan keunggulan kompetitif. Penelitian ini menggunakan kerangka intellectual capital dimana komponen intellectual capital diidentifikasikan dalam konsep input-proses-output untuk menggambarkan hubungan antara sumber daya dan nilai dalam proses penciptaan nilai.

Keempat komponen intellectual capital: innovation capital, process capital, human capital, dan customer capital berasal dari persepsi manajerial dan tidak secara langsung diukur dalam laporan keuangan. Komponen-komponen intellectual capital tersebut menjadi innovative capacity, efficient operating processes, human value added, dan maintainable customer relationship sehingga ukuran keuangan dapat digunakan untuk mengembangkan model jalur struktural yang menghubungkan antara intellectual capital dan kinerja perusahaan.

Tidak adanya pengaruh signifikan positif intellectual capital terhadap nilai perusahaan tidak didukung oleh penelitian Rachman dan Marsono (2014). Hasil penelitian ini menunjukkan bahwa intellectual capital yang diproksikan dengan human capital, customer 
capital, innovation capital, dan process capital berpengaruh positif terhadap nilai perusahaan. Penelitian lain yang memiliki hasil tidak serupa adalah penelitian yang dilakukan oleh Yusuf dan Gasim (2015) serta Sukiati, dkk (2015) yang menyatakan bahwa intellectual capital berpengaruh positif terhadap nilai perusahaan.

\section{Pengaruh Ukuran Perusahaan terhadap Nilai perusahaan dengan Dimoderasi oleh Kinerja Keuangan}

Ukuran perusahaan tidak berpengaruh terhadap nilai perusahaan dengan dimoderasi oleh kinerja keuangan pada perusahaan yang terdaftar di Indeks Saham Syariah Indonesia periode 2013-2017. Tidak sesuai dengan pernyataan Jansen dan Meckling (1976) menggambarkan hubungan keagenan sebagai hubungan yang timbul karena adanya kontrak antara principal (pemegang saham) yang menggunakan agent (manajemen pengelola perusahaan) untuk melakukan jasa. Salah satu faktor yang dapat dijadikan sebagai dasar pertimbangan dalam pengambilan keputusan investasi adalah kinerja keuangan perusahaan.

Perusahaan besar lebih konsisten untuk tepat waktu dibanding perusahaan kecil dalam mengnformasikan laporan keuangannya, karena perusahaan besar banyak disorot oleh masyarakat. Perusahaan besar mempunyai pengetahuan lebih tentang peraturan yang ada, oleh karena itu perusahaan besar lebih mentaati peraturan mengenai ketepatan waktu dibanding perusahaan kecil. Namun demikian tidak menutup kemungkinan bahwa perusahaan besar cenderung melaporkan laporan keuangannya tidak tepat waktu mengingat banyaknya cabang usaha serta banyaknya anak perusahaan yang dimilikinya, sehingga penyusunan laporan keuangan akan lebih rumit dan lama.

Tidak adanya pengaruh signifikan positif ukuran perusahaan terhadap nilai perusahaan didukung oleh penelitian Kinanti dan Nuzula (2017). Hasil penelitian ini menunjukkan bahwa ukuran perusahaan yang diproksikan dengan logaritma natural total aset berpengaruh positif terhadap nilai perusahaan. Penelitian lain yang memiliki hasil yang tidak serupa adalah penelitian yang dilakukan oleh Rahmawati, dkk (2017) yang menyatakan bahwa ukuran perusahaan berpengaruh positif terhadap nilai perusahaan.

Pengaruh Intangible Asset Value terhadap Nilai perusahaan dengan Dimoderasi oleh Kinerja Keuangan

Intangible Asset Value tidak berpengaruh terhadap nilai perusahaan dengan dimoderasi oleh kinerja keuangan pada perusahaan yang terdaftar di Indeks Saham Syariah Indonesia periode 2013-2017. Tidak sesuai dengan Resource Based Theory (RBT), perusahaan harus 
memiliki sumber daya yang lebih superior dibandingkan perusahaan lain untuk dapat menciptakan keunggulan kompetitif. Aset tidak berwujud memiliki peran penting dalam mencapai tujuan dan strategi perusahaan serta dalam menentukan nilai perusahaan.

Penggunaan pengetahuan yang menghasilkan inovasi serta sebagai landasan untuk meningkatkan responsivitas terhadap kebutuhan pelanggan dan stakeholders. Pengetahuan juga bermanfaat untuk meningkatkan produktivitas dan kompetensi karyawan yang telah diberi tanggung jawab. Manfaat yang diperoleh perusahaan dari meningkatnya kompetensi karyawan dan adanya inovasi adalah meningkatnya competitive advantage (Soraya dan Syafruddin, 2016).

Tidak adanya pengaruh signifikan positif ukuran perusahaan terhadap nilai perusahaan didukung oleh penelitian Kinanti dan Nuzula (2017). Hasil penelitian ini menunjukkan bahwa ukuran perusahaan yang diproksikan dengan logaritma natural total aset berpengaruh positif terhadap nilai perusahaan. Penelitian lain yang memiliki hasil tidak serupa adalah penelitian yang dilakukan oleh Rahmawati, dkk (2017) yang menyatakan bahwa ukuran perusahaan berpengaruh positif terhadap nilai perusahaan.

\section{Pengaruh Intellectual Capital terhadap Nilai perusahaan dengan Dimoderasi oleh Kinerja Keuangan}

Intellectual Capital berpengaruh positif terhadap nilai perusahaan dengan dimoderasi oleh kinerja keuangan pada perusahaan yang terdaftar di Indeks Saham Syariah Indonesia periode 2013-2017. Berdasarkan Resource Based Theory (RBT), perusahaan harus memiliki sumber daya yang lebih superior dibandingkan perusahaan lain untuk dapat menciptakan keunggulan kompetitif. Dasar pemikiran utama RBT menyatakan bahwa kemampuan menciptakan nilai perusahaan tidak berasal dari dinamika industri perusahaan, tetapi berasal dari proses organisasional yang mengarahkan pada keistimewaan sumber daya yang dimiliki. RBT mengkaji sifat dasar dan kualitas sumber daya dalam proses penciptaan nilai, tetapi tidak menyediakan suatu kerangka yang menjelaskan proses persebaran dan bagaimana nilai perusahaan terbentuk; hubungan antara sumber daya (input) dan nilai perusahaan (output) terasumsikan dalam kerangka, tetapi tidak dijelaskan (Rachman dan Marsono, 2014).

RBT tidak mampu menggambarkan proses penciptaan nilai yang terjadi, sehingga manajer tidak dapat mengetahui kerangka kerja yang tepat untuk menjelaskan bagaimana input sumber daya menjadi output selama proses penciptaan nilai. Perspektif intellectual capital menyediakan jembatan penghubung antara sumber daya dan nilai dengan 
memfokuskannya pada pencarian metode terbaik untuk mengolah dan memanfaatkan nilai maksimum dari sumber daya yang ada. Penelitian ini menggunakan kerangka intellectual capital dimana komponen intellectual capital diidentifikasikan dalam konsep input-prosesoutput untuk menggambarkan hubungan antara sumber daya dan nilai dalam proses penciptaan nilai.

Adanya pengaruh signifikan positif kinerja keuangan terhadap nilai perusahaan didukung oleh penelitian Abadiah, Hidayati dan Mawardi (2016) serta Kombih dan Suhardianto (2017). Hasil penelitian ini menunjukkan bahwa kinerja keuangan yang diproksikan dengan return on asset (ROA) berpengaruh positif terhadap nilai perusahaan. Hasil penelitian Yusuf dan Gasim (2015) menunjukkan bahwa intellectual capital yang diproksikan dengan human capital, customer capital, innovation capital, dan process capital berpengaruh positif terhadap nilai perusahaan.

\section{SIMPULAN}

Simpulan yang diperoleh dari hasil penelitian dan pembahasan adalah ukuran perusahaan dan intellectual capital tidak berpengaruh terhadap nilai perusahaan pada perusahaan yang terdaftar di Indeks Saham Syariah Indonesia. Intangible asset value berpengaruh positif signfikan terhadap nilai perusahaan pada perusahaan yang terdaftar di Indeks Saham Syariah Indonesia. Ukuran perusahaan dan Intangible Asset Value tidak berpengaruh terhadap nilai perusahaan dengan dimoderasi oleh kinerja keuangan pada perusahaan yang terdaftar di Indeks Saham Syariah Indonesia. Intellectual Capital berpengaruh positif terhadap nilai perusahaan dengan dimoderasi oleh kinerja keuangan pada perusahaan yang terdaftar di Indeks Saham Syariah Indonesia. Penelitian selanjutnya diharapkan dapat menggunakan alternatif variabel lain untuk digunakan sebagai variabel mediasi, dikarenakan pada penelitian ini kinerja keuangan hanya dapat memediasi pengaruh intellectual capital, serta tidak memediasi pengaruh ukuran perusahaan, intangible asset value yang digunakan dalam penelitian ini. Variabel perantara tersebut antara lain umur perusahaan dan pertumbuhan perusahaan. Penelitian selanjutnya diharapkan dapat lebih menyempurnakan penelitian terkait variabel-variabel yang dapat mempengaruhi nilai perusahaan, karena dalam penelitian ini memiliki nilai adjusted $R$ 43,6\%, maka masih terdapat variabel lain yang mungkin mempengaruhi nilai perusahaan. Variabel tersebut antara lain profitabilitas, leverage dan kualitas laba. 


\section{DAFTAR PUSTAKA}

Abadiah, Tsamrotul Masrifatil, Nur Hidayati dan Cholid Mawardi. (2016). Analisis Pengaruh Aset Tidak Berwujud dan Kinerja Keuangan terhadap Nilai Perusahaan Studi Empiris terhadap Perusahaan Manufaktur yang Terdaftar di BEI Tahun 2013-2015. Jurnal Akuntansi 47.

Arikunto, Suharsimi. (2013). Prosedur Penelitian Suatu Pendekatan Praktik. Jakarta: Rineka Cipta.

Brigham and Houston. (2017). Dasar-Dasar Manajemen Keuangan. Jakarta: Salemba Empat.

Cahyaning, Anugraheni Murti. (2010), "Pengaruh Intellectual Capital terhadap kinerja perusahaan perusahaan manufaktur yang listing di BEI tahun 2006-2008."

Gamayuni. (2018). Pengaruh Intangible Asset, Kebijakan Keuangan, dan Kinerja Keuangan terhadap Nilai Perusahaan. Jurnal Ekonomi dan Bisnis. Universitas Lampung.

Ghozali, Imam. (2016). Aplikasi Statistik Menggunakan SPSS. Semarang: BP Universitas Diponegoro.

Herawati, Titin. 2012. Pengaruh Kebijakan Dividen, Kebijakan Hutang, dan Profitabilitas Terhadap Nilai Perusahaan. Jurnal Manajemen. 2(2) h: 1-18.

Husnan, Suad. (2015). Manajemen Keuangan Teori dan Penerapan (Keputusan Jangka Panjang). Edisi 4. Yogyakarta: BPFE Yogyakarta.

Irawan. (2016). Pengantar Ekonomi Perusahaan. Yogyakarta: BPFE Yogyakarta.

Jensen and Meckling. (1976). Theory of the Firm: Managerial Behavior, Agency Costs and Ownership Structure. Journal of Financial Economics, October, 1976, V. 3, No. 4, pp. 305-360.

Lubis, Arnida Wahyuni, Rina Bukit, Tapi Anda Sari Lubis. (2013). Pengaruh Pengeluaran Modal, Penelitian dan Pengembangan, Transaksi Pihak Hubungan Istimewa dan Profitabilitas terhadap Nilai Perusahaan pada Perusahaan Manufaktur yang Terdaftar di Bursa Efek Indonesia. Jurnal Telaah \& Riset Akuntansi Vol. 6 No. 1 Januari 2013.

Mahdita, Silfyana Cahya Manggar. (2017). Pengaruh Intensitas Research And Development dan Kinerja Perusahaan terhadap Nilai Perusahaan. Jurnal S-1 Akuntansi. Universitas Negeri Surabaya.

Mamduh, M. Hanafi. (2014). Manajemen Keuangan. Yogyakarta: BPFE Yogyakarta.

Munawir. (2010). Analisa Laporan Keuangan. Yogyakarta: Liberty.

Nuraeni, Elfreda Aplonia Lau dan Rina Masyithoh Haryadi. (2015). Pengaruh Leverage, Profitability, Market Value dan Ukuran Perusahaan terhadap Nilai Perusahaan 
Property yang Terdaftar di BEI Tahun 2012-2014. Jurnal Akuntansi. Universitas 17 Agustus 1945 Samarinda.

Setijawan, Imam. (2015). Pengaruh Asset Tidak Berwujud terhadap Nilai Perusahaan. Aset, September 2015, Vol. 13 No. 2.

Setiono, Arif Pajar dan Deny Dwi Hartomo. (2016). R\&D, Nilai Perusahaan dan Karakteristik Perusahaan. Fokus Manajerial 2016 - Vol. 14 No.1 Hal. 39-50.

Sugiarto. 2011. Struktur Modal, Struktur Kepemilikan Perusahaan, Permasalahan Keagenan dan Informasi Asimetri. Edisi Pertama. Graha Ilmu, Yogyakarta.

Sujoko dan Ugy Soebiantoro. (2007). Pengaruh Struktur Kepemilikan, Leverage, Faktor Intern, dan Faktor Ekstern terhadap Nilai Perusahaan (Studi Empirik pada Perusahaan Manufaktur dan Non Manufaktur di Bursa Efek Jakarta). Jurnal Manajemen dan Kewirausahaan, Vol. 9. No. 1.

Sukirni, Dwi. (2012). Kepemilikan Manajerial, Kepemilikan Institusional, Kebijakan Deviden dan Kebijakan Hutang Analisis Terhadap Nilai Perusahaan. Accounting Analysis Journal. Universitas Negeri Semarang. 